\title{
CORRESPONDENCE
}

\author{
Correspondents are asked to be brief
}

Prevention of Hyaline Membrane Disease

P. Johnson, M.B. . . . . . . . . . . . . . . . .660

"Indian Colonel Syndrome"?

R. Cilento, M.D................660

Bronchospasm following Althesin

Anaesthesia

Lt. Col. T. R. Austin, F.F.A.R.C.S., and others. 661

Actinomycin D for Wilms's Tumour

H. W. C. Ward, M.R.C.P., F.F.R. . . . . . . 661

Drug-induced Respiratory Disorders

Z. Farid, M.D., and others...........6661

Propranolol and the Hyperactive Carotid Sinus Refiex Syndrome

A. J. Reyes, M.D...........

New Ideas on Vitamin $D$

H. F. DeLuca . . . . . . . . 662

Malignancy of Bronchial Adenoms

V. T. Powell, F.R.C.S.ED. . . . . . . . . .6662

Haematology and Biochemistry of Ankylosing Spondylitis

D. N. Golding, F.R.C.P.I...

Amyloidosis and the Kidney

H. Baker, F.R.C.P.............663
Supporting Service for the Mentally Handicapped

R. C. MacGillivray, F.R.C.P.GLASG., and

D. A. A. Primrose, M.D. . . . . . . . . 663

Treatment of Status Asthmaticus

N. G. Kounis, M.D...........663

Actinomycosis

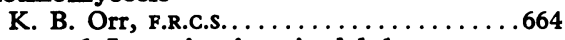

Research Investigations in Adults

R. J. Shephard, M.D. . . . . . . . . . . . .664

Medical Stafi Dining-rooms

M. Beryl Bailey, A.L.A... . . . . . . . . . . . .664

Lead in Drinking Water

E. I. Hamilton, D.PHIL. . . . . . . . . . . .664

Pruritus Vulvae

Sally E. Ford, M.B.; Katherine M. Venables.665

The No-touching Epidemic

C. F. J. Cropper, F.R.C.P.ED. . . . . . . .665

Arrhythmias in the Guillain-Barré

Syndrome

I. M. Stewart, M.R.C.P...

Public Attitudes to A.I.D.

D. Pariente, M.B...............666
Vitreous Surgery

J. Williamson, F.R.C.S.GLASG. . ........666

Aetiology of Acute Glomerulonephritis

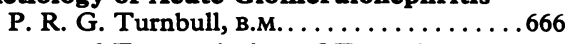

Dogs and Transmission of Toxoplasmosis

M. B. Markus, M.sc. . . . . . . . . . . . .666

Isolation in the Control of Dysentry

R. G. Hendrickse, F.R.C.P.ED. . . . . . . .666

Sarcoma after Intramuscular Iron

Injection

P. Grasso, M.D., M.R.C.PATH. . . . . . . .667

Neurological Disease associated with

Folate Deficiency

P. W. Hutton, F.R.C.P. . . . . . . . . . . 667

Mediterranean Anaemia in Antiquity

H. A. Waldron, M.B........... . .667

Rabies

D. Ikedife, M.B., M.R.C.o.G. . . . . . . . .667

Purpura Associated with Vomiting

P. W. Pitt, M.B...................667

Work Fit for a Consultant ?

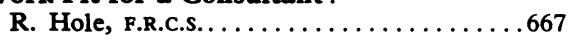

\section{Prevention of Hyaline Membrane Disease}

$S_{i R}$,-In your leading article on this subject (14 April, p. 65), the recent reports of trials of corticosteroid therapy both pre- and postnatally were rightly highlighted. It was also stated that much of the rationale for these trials was derived from animal work.

At the present time perinatal care is more than ever committed to providing for the quality of life and not merely survival. However, evaluation of the animal work which stimulated the human trials, and presumably the leading article, shows little to indicate that viability was enhanced by the administration of corticosteroids. The tacit assumption that enhanced pulmonary maturation can be equated with viability in all species is far from proved. In fact, viability, the capacity to maintain life, has readily been implied from work that has shown only enhanced pulmonary maturation.

In the remarkable observations of Liggins in $1969^{1}$ relating premature induction of labour and coincident prematuration of the lung to corticosteroid infusion, it should be noted that nine of 10 spontaneously delivered lambs were actually found dead, though with evidence of lung aeration. The tenth showed signs of respiratory distress before death. While these observations in lambs of 117-123 days' gestation clearly indicated a significant beneficial effect on lung maturation, little could be said about viability.

In fact Delemos, ${ }^{2}$ in work concentrating on the mode and manner of accelerated pulmonary maturation, stated that no lamb whose birth was induced prematurely following hydrocortisone infusion survived more than 12 hours. In these experiments it was shown that when pressure-volume curves were constructed neither the volume per gramme at maximal pressure nor the percentage retained at atmospheric pressure was as great as in the full-term lambs. Whether it is this factor or others related to the effect or lack of effect of corticosteroid on other systems which determines survival is not known. In an earlier review ${ }^{3}$ the possible detrimental effects of steroid administration to the fetus were mentioned, ranging from reduced cell number in the lungs of rabbits so treated to permanent neurological deficits in rats. ${ }^{5}$ Is there a price to be paid, or can catch-up growth occur?

Recent work by Alexander ${ }^{6}$ has shown that surviving premature lambs following corticotrophin infusion lack a response to thermal stress and moreover do not improve with age in this respect. This is the first report pertaining to the quality of survival. In the human, among recent advances in the management of the respiratory distress syndrome, Gluck $^{7}$ has advanced his preliminary information to show that the amniotic lecithin: sphingomyelin ratio correlates well with "functional maturity" and not simply gestational age. In addition, the introduction of continuous positive airway pressure, ${ }^{8}$ especially when used early in the disease, ${ }^{9}$ has certainly provided a suocessful alternative form of management of the syndrome in the preterm infant, reducing mortality successively from $33 \%$ to $14.7 \%$ to $4.9 \%$. It is clear that the management of the at-risk preterm fetus must be based on the careful assessment of several perinatal factors in each individual case.

It is the purpose of this letter to help place the conclusions drawn by others from a very significant observation in their true perspective. Indeed, the initial observation is likely to have more far-reaching implications in the physiology and pathology of the perinatal period than hyaline membrane disease.-I am, etc.,

P. Johnson

Nuffield Institute for Medical Research,
1 Liggins, G. G., fournal of Endocrinology, 1969, 45, 515, Delemos, R. A., Shermeta, D. W., Knelson, J. H., of Respiratory Diseases, 1970, 102.459. Avery, M. E., Pediatrics, 1972, 50, 513.

Carson, S. H., Taeusch, H. W., and Avery, M. E. Federation Proceedings, 1972, 31 (abstracts), 238 docrinology, 1968, 10, and

docrinology, 1968, 10, 214. Foetal and Neonatal Physiology. Proceedings Sir foetal and Neonatal Physiology. Proceedings Sir Foseph Barcroft Centenary Symposium, ed. University Press, 1973.

Gluck, L., and Kulovich, M. V., American
fournal of Obstetrics and Gynecology, 1973, fournal of Obstetrics and Gynecology, 1973, 8 Gregory, G. A., Kitterman, J. A., Phibbs, R. H., Tooley, W. H., and Hamilton, W. K., New England fourmal of Medicine, 1971, 284, 1333.
Dunn, P. M., Proceedings of the Royal Society of Medicine. In press.

\section{"Indian Colonel Syndrome"?}

SIR,-During the past 13 years I have observed hypervolaemic-type hypertension with water retention and (since I started measuring them recently) elevated aldosterone levels in people born and raised in, or acclimatized while young to, the tropics.

Recently I have checked 20 such persons of both sexes in the 50-60-year age group, as nearly matched as possible, using very sophisticated gamma-camera equipment and found no renal or cardiac compromise of note, while 20 hypertensive natives of Detroit matched as nearly as possible in respect of age and physical condition all showed varying degrees of renal damage and other evidence of hypertensive-arteriosclerotic mosaic disease, or so-called A.S.C.V. mosaic disease.

Over the age of 60 there is little difference in the incidence of A.S.C.V. mosaic disease in the two groups, with the main pathology illustrated by (often unsuspected) advanced renal lesions and coronary artery compromise with left ventricular preponderance. This was unsuspected in many cases because the results of the usual tests for disease in these 